\title{
Therapeutic Effect of Resveratrol on Morphine-Induced Damage in Male Reproductive System of Mice by Reducing Nitric Oxide Serum Level
}

\author{
Efecto Terapéutico de Resveratrol Sobre el Daño Inducido por la Morfina en el Sistema \\ Reproductor Masculino de Ratones Reduciendo el Nivel de Óxido Nítrico del Suero
}

\author{
Cyrus Jalili' ${ }^{1}$; Mohammad Reza Salahshoor ${ }^{1}$; Faramarz Jalili² $^{2}$ Seyran Kakabaraei ${ }^{1}$; \\ Ali Akrami ${ }^{3}$; Maryam Sohrabi ${ }^{1}$; Maryam Ahookhash ${ }^{1}$ \& Ali Ghanbari ${ }^{1}$
}

\begin{abstract}
JALILI, C.; SALAHSHOOR, M. R. ; JALILI, F; KAKABARAEI, S.; AKRAMI, A.; SOHRABI, M.; AHOOKHASH, M. \& GHANBARI, A. Therapeutic effect of resveratrol on morphine-induced damage in male reproductive system of mice by reducing nitric oxide serum level. Int. J. Morphol., 35(4):1342-1347, 2017.

SUMMARY: Morphine is one of the naturally occurring phenanthrene alkaloids of opium that induces adverse effects on male reproductive system. Resveratrol is a phytoestrogen and antioxidant of red grape. The main goal is to investigate whether resveratrol could inhibit adverse effects of morphine on sperm cell viability, count, motility as well as testis histology, testosterone hormone and nitric oxide levels in mice. In the present study, 48 male rats were randomly divided into 8 groups $(\mathrm{n}=6)$ and were treated intraperitoneally for 14 days with normal saline, resveratrol $(2,8,20 \mathrm{mg} / \mathrm{kg} / \mathrm{day})$, morphine (20 mg/kg/day) and morphine (20 mg/kg/day) + resveratrol (2, $8,20 \mathrm{mg} / \mathrm{kg} / \mathrm{day}$ ). At the end of experiments, sperm parameters (sperm cell viability, count, motility and morphology), testis weight, the diameter of seminiferous tubules, testosterone hormone level and nitric oxide were analyzed. The data were analyzed by SPSS software for windows (version 20) using one-way ANOVA test followed by Tukey's post hoc test, and $\mathrm{P}<0.05$ was considered significant. The results indicated that morphine administration significantly decreased testosterone level, count, viability and motility of sperm cells and testis weight and increased nitric oxide compared to the saline group $(\mathrm{P}=0.000)$. Administration of resveratrol and resveratrol plus morphine significantly increased motility, count and viability of sperm cells, somniferous tubule diameter and testosterone, while it decreased nitric oxide level compared to morphine group $(\mathrm{P}=0.025)$. It seems that resveratrol administration could increase the quality of spermatozoa and prevented morphine-induced adverse effects on sperm parameters.
\end{abstract}

KEY WORDS: Mice; Morphine; Nitric Oxide; Resveratrol; Spermatogenesis.

\section{INTRODUCTION}

Morphine is one of the constituents of opium which has favorable pharmacological effects, while its non-drug overuse has adverse and destructive consequences on tissues (Wise, 2004). However, researches are continuing to identify the molecular pathways regarding morphine hazardous effects on tissues. At molecular level, the side effects of morphine have been shown by activating lipid per oxidation, increasing the free radicals such as reactive oxygen species (ROS) and releasing nitric oxide (NO). The release of NO could also be considered as a part of dependency on morphine (Motahari et al., 2016). These data indicate the role of oxidation and inflammation processes during morphine interaction with tissues.
Many studies have revealed the infertility effects of morphine administration on males by decreasing testosterone serum level and inducing histological damage on testis and sperms (Yilmaz et al., 1999; Moradi et al., 2014). Studies have shown the existence of morphine receptors in sertoli and leydig cells of testis and have further addressed the involvement of inflammation and oxidation during male reproductive system exposure to morphine by producing NO and regulating inflammatory cascades (Jalili et al., 2016; Chehrei et al., 2017).

Resveratrol, found in many foods such as grape, is a phytoalexin with antioxidant, anti-inflammatory, and anti-

\footnotetext{
${ }^{1}$ Fertility and Infertility Research Center, Kermanshah University of Medical Sciences, Kermanshah, Iran

${ }^{2}$ Student of Pharmacy, Kermanshah University of Medical Sciences, Kermanshah, Iran

${ }^{3}$ Student of Medicine, Kermanshah University of Medical Sciences, Kermanshah, Iran
} 
cancer properties (Bai et al., 2017). The beneficial effects of resveratrol on male reproductive system have been approved by many authors addressing the antioxidant properties of this natural product. In this regard, many molecular pathways have been monitored (Ourique et al., 2016), but the role of NO as an important molecule involved in inflammation responses in resveratrol recovery process of male reproductive system is not well understood.

Hence, the present study was conducted to investigate the therapeutic effect of resveratrol on morphine-induced disturbances in male reproductive system. We evaluated sperm parameters (motility, count, viability and morphology), testicular histology, testosterone serum and nitric oxide level of treated mice.

\section{MATERIAL AND METHOD}

Chemicals. Resveratrol (trans-3, 4, 5-trihydroxystilbene) was purchased from Sigma-Aldrich Company, was weighed according to the desired concentrations and was then dissolved in $50 \%$ ethanol and $9.0 \%$ normal saline until the desired volume was reached). Morphine, [(5a, 6a)-7, 8-didehydro- 4, 5-epoxy-17-methylmorphinan-3, 6-diol], was purchased from Sigma-Aldrich Company and diluted with saline.

Animal treatment. Forty eight male mice BALB/cwith a weight range of 27-30 g were purchased from Razi Institute of Iran, and all animals were housed in plastic cages in a conditioned atmosphere at $20 \pm 2{ }^{\circ} \mathrm{C}$ with 12 -h light/dark cycles. The mice had unrestricted access to food and water. All the mice were randomly divided into eight groups $(6$ mice/ group).Group 1 (Control group) received normal saline solution, group 2 (positive control) received $20 \mathrm{mg} / \mathrm{kg}$ of morphine, groups 3, 4, 5 received 2,8 and $20 \mathrm{mg} / \mathrm{kg}$ of resveratrol respectively and groups 6,7 and 8 were administrated morphine $(20 \mathrm{mg} / \mathrm{kg})$ following pretreatment with 2,8 and $20 \mathrm{mg} / \mathrm{kg}$ of resveratrol, respectively. All animals received the drugs by intraperitoneal injection daily in the morning for 2 weeks (Ranawat et al., 2014). Twenty four hours after the last injection, the mice were necropsied by ether while they were in deep anesthesia. Finally, testicles were removed from the mice abdomen and were weighed by digital scale (A\&D GF600). All the surgical and experimental procedures were in accordance with institutional animal care guidelines.

Sperm parameter evaluation. The abstracted cauda epididymides wer transferred into a Petri dish containing DMEM/F12 (Gibco- Cat.32500-05) and were incubated at 37 ${ }^{\circ} \mathrm{C}, \mathrm{CO}_{2}(5 \%)$ for 7 minutes (Jalili et al., 2014). Fifty $\mathrm{ml}$ of the culture medium containing semen liquid was removed and placed on glass slide, and sperm motility was evaluated by a light microscope with a magnification of $40 \times$ in ten vision fields based on WHO procedure. Sperm count was conducted via cell counter. The vitality and morphology of sperms were analyzed using eosin (Y: MERCK, 1.15935.0025) staining technique. Live cells appeared to be colorless and dead cells appeared to be red or pink in color. The defects in the head and tail of sperms were also assessed.

Testis histological characterization. Testes were removed and fixed in $10 \%$ formalin. The abstracted testes were trimmed transversely into three parts. The middle part was then immersed in $70 \%$ alcohol, followed by immersions in a series of alcohol solutions with ascending concentrations. After a dehydration process, the tissue samples were then processed further before being sectioned ( $5 \mu \mathrm{m}$ thick) using microtome (EC350-2). Haematoxylin and Eosin (H\&E) staining technique would stain the nucleus purple and the cytoplasm pink. The steps of the H\&E staining technique included deparaffinization, hydration, haematoxylin and eosin staining, dehydration and clearing. The features evaluated were the diameter of seminiferous tubules and germinal epithelium height.

Nitric oxide (NO) measurement. Nitric oxide was measured by Griess reaction using zinc sulfate powder for removing proteins from serum samples. For this purpose, $6 \mathrm{mg}$ of zinc sulfate powder was mixed with $400 \mathrm{ml}$ of serum samples in micro tubes and were vortexed for one minute. After mixing, the samples were centrifuged for 10 minutes at 12,000 revolutions per minute (rpm) at $4{ }^{\circ} \mathrm{C}$. Then, upper solution (supernatant) was used to measure NO (NOx). Briefly, a 50 $\mathrm{ml}$ sample was added with $100 \mathrm{ml}$ of Griess reagent (Sigma) and reaction mixture was incubated for about $30 \mathrm{~min}$ at room temperature, being protected from light. The optical density was measured at $450 \mathrm{~nm}$ in micro plate reader according to the reagent manufacturer's protocol (Miranda et al., 2001).

Testosterone serum level assessment. Blood was drawn from the heart for serum estimations. Blood samples taken from the heart were incubated for 30 minutes and centrifuged for 30 minutes at $2500 \mathrm{rpm}$ to obtain the serum. The serum samples were stored in a freezer $\left(-20^{\circ} \mathrm{C}\right)$. The blood testosterone level was determined by ELISA (Abcam 108666, USA) method using a specific kit (Monobind Company, USA).

\section{RESULTS}

Evaluation of left testicular weight changes in treated groups. The results of the left testis weight between the groups showed a significant decrease in testicular weight in 
the group receiving morphine compared to the control group. In the group receiving morphine + resveratrol at a dose of $20 \mathrm{mg} / \mathrm{kg}$, a significant increase in testicular weight was observed in comparison to control group. Although testicular weight in the groups receiving morphine + resveratrol at doses of 2, 8 and $20 \mathrm{mg} / \mathrm{kg}$ was increased compared to the group receiving only morphine, statistical analysis showed no significant difference. Testicular weight in the groups receiving morphine + resveratrol at doses of 2, 8 and $20 \mathrm{mg} /$ $\mathrm{kg}$ was increased, but compared to the group receiving only morphine, statistical analysis did not show any significant difference (Fig. 1A).

Measurement of nitric oxide levels. Evaluation of serum levels of NO showed a significant decrease in the group receiving morphine compared to the saline group $(\mathrm{p}=0.002)$. In the group receiving morphine + resveratrol at a dose of $20 \mathrm{mg} / \mathrm{kg}$, a significant reduction was found in serum levels of NO compared to the control group ( $\mathrm{p}=0.002)$ (Fig.1B).

\section{Sperm parameter evaluation}

The number of sperms. The results of counting the number of sperms in the study groups showed a significant reduction in the group receiving morphine compared to the saline group. Despite the increased number of sperms in groups receiving 2,8 and $20 \mathrm{mg} / \mathrm{kg}$ resveratrol compared to saline group, no statistically significant differences were observed. Also, in the groups receiving morphine + resveratrol at doses of 2,8 and $20 \mathrm{mg} / \mathrm{kg}$, there was no significant change (Table I).

Sperm viability. The results of sperm viability in study groups showed a significant decrease in the group receiving morphine compared to the saline group $(\mathrm{p}=0.000)$. There was a significant increase in viability of sperm in the group receiving $20 \mathrm{mg} / \mathrm{kg}$ of resveratrol compared with the saline group. In the group receiving morphine + resveratrol at a dose of $20 \mathrm{mg} / \mathrm{kg}$, sperm viability significantly increased compared to the morphine group $(\mathrm{p}=0.003)$ (Table I).

Sperm morphology. The results of sperm morphology in the study groups showed a significant decrease in the group receiving morphine, compared to the saline group $(\mathrm{p}=0.000)$. Further, a significant increase was observed in the group receiving morphine + resveratrol at a dose of 20 $\mathrm{mg} / \mathrm{kg}$ compared to the morphine group $(\mathrm{p}=0.005)$. Despite the increase in the number of normal sperms in the groups receiving resveratrol at doses of 2,8 and $20 \mathrm{mg} / \mathrm{kg}$ compared with the control group, no statistically significant difference was found (Table I).

Sperm motility. Evaluation of high sperm motility showed a significant decrease in morphine-treated group compared to the saline group $(\mathrm{p}=0.000)$; however, a significant increase was observed in the groups receiving morphine + resveratrol at doses of 2,8 and $20 \mathrm{mg} / \mathrm{kg}$ compared to the group receiving only morphine $(\mathrm{p}=0.005)$. Also, a significant increase in progressive sperm motility was reported in the group receiving resveratrol at $20 \mathrm{mg} / \mathrm{kg}$ compared to the saline group (Table I).

Seminiferous tubule diameter evaluation. The results of the analysis of seminiferous tubule diameter showed significant decrease in the group receiving morphine compared to the saline group $(\mathrm{P}=0.000)$. Although seminiferous tubule diameter was increased in the group receiving resveratrol compared to saline group, this increase was not statistically significant. In the group receiving morphine + resveratrol at a dose of $20 \mathrm{mg} / \mathrm{kg}$, there was a significant increase in seminiferous tubule diameter compared to the control group $(\mathrm{P}=0.004)$ (Table I).
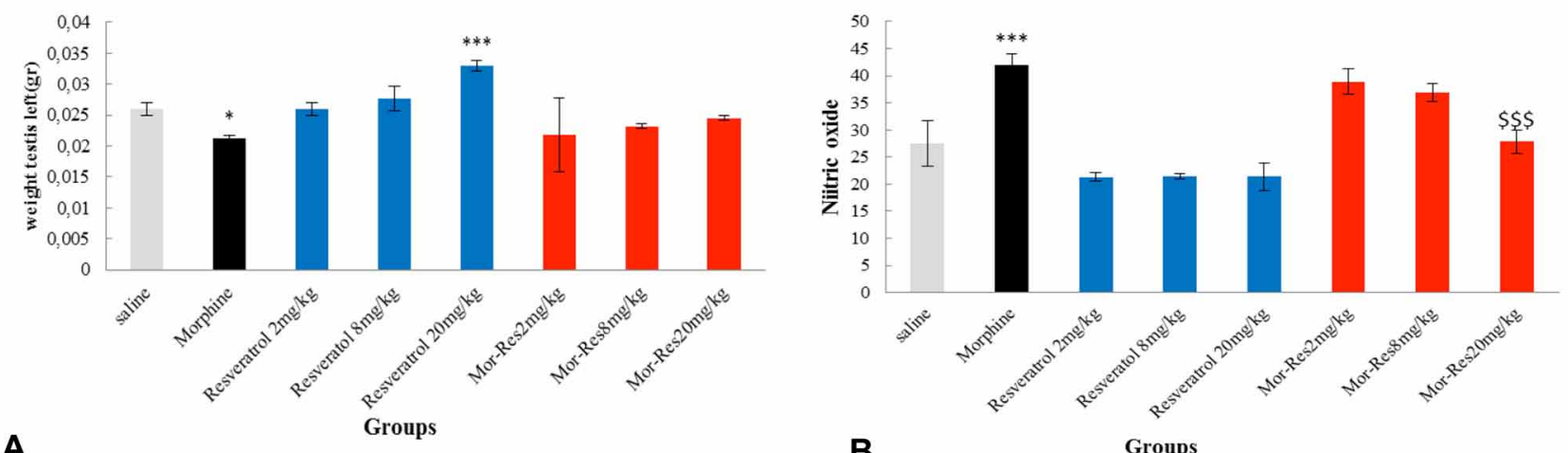

\section{A}

Fig. 1. Resveratrol and morphine effect on testis weight (A) and on serum level of Nitric oxide of mice $(\mathrm{B})$. $(\mathrm{Mor}=\mathrm{Morphine}$, Res= Resveratrol) $\$ \$ \$=\mathrm{P}<0.05$ compared with the morphine group. $* * *=\mathrm{P}<0.01$ compared with the control group. $*=\mathrm{P}<0.05$ compared with the control group. 


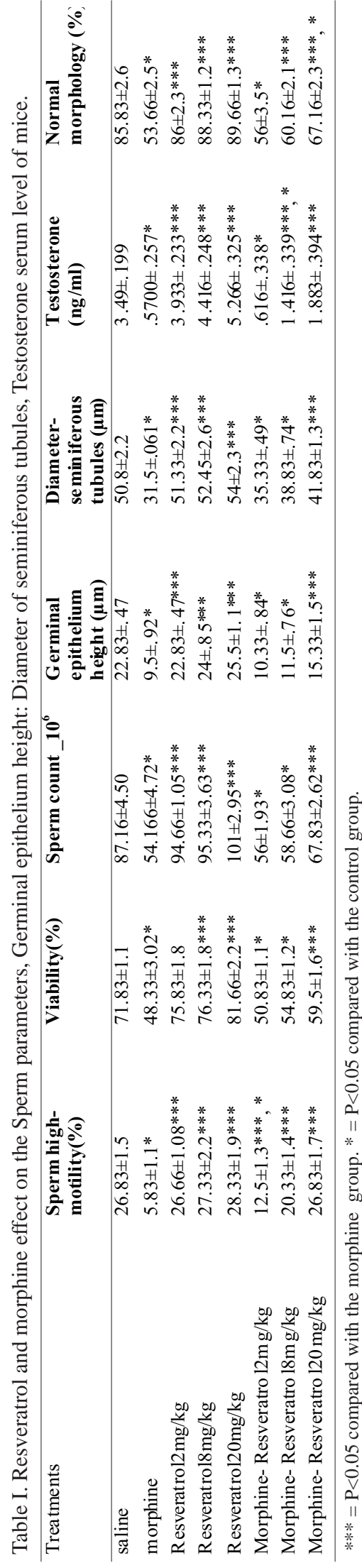

Evaluation of germinal epithelium height of seminiferous tubule in the treated groups. The results of germinal epithelium height showed a significant decrease in the morphine group compared to the saline group $(\mathrm{p}=0.000)$. In the group receiving morphine + resveratrol at a dose of $20 \mathrm{mg} / \mathrm{kg}$ significant increase in the height of germinal epithelium in comparison with the control group was observed $(p=0.002)$ (Table I). Despite the increase in the group receiving resveratrol compared with the control group, the increase was not statistically significant.

Effect of morphine and resveratrol on serum testosterone levels. Evaluation of serum levels of testosterone showed a significant decrease in the group receiving morphine compared to the saline group $(\mathrm{p}=0.000)$. Also, a significant increase was observed in the group receiving resveratrol at a dose of $20 \mathrm{mg} / \mathrm{kg}$ compared to saline group $(\mathrm{p}=0.003)$. In the group receiving morphine + resveratrol at a dose of $20 \mathrm{mg} / \mathrm{kg}$, a significant increase was observed in serum testosterone levels compared to the control group ( $\mathrm{p}=0.000)$ (Table I).

Testis histological features. A significant reduction of germinal cells height was observed in morphine group compared to the control group, while in the group receiving morphine + resveratrol at a dose of $20 \mathrm{mg} / \mathrm{kg}$, a significant increase were reported in the height of germinal epithelium in comparison with the morphine group (Fig. 2).

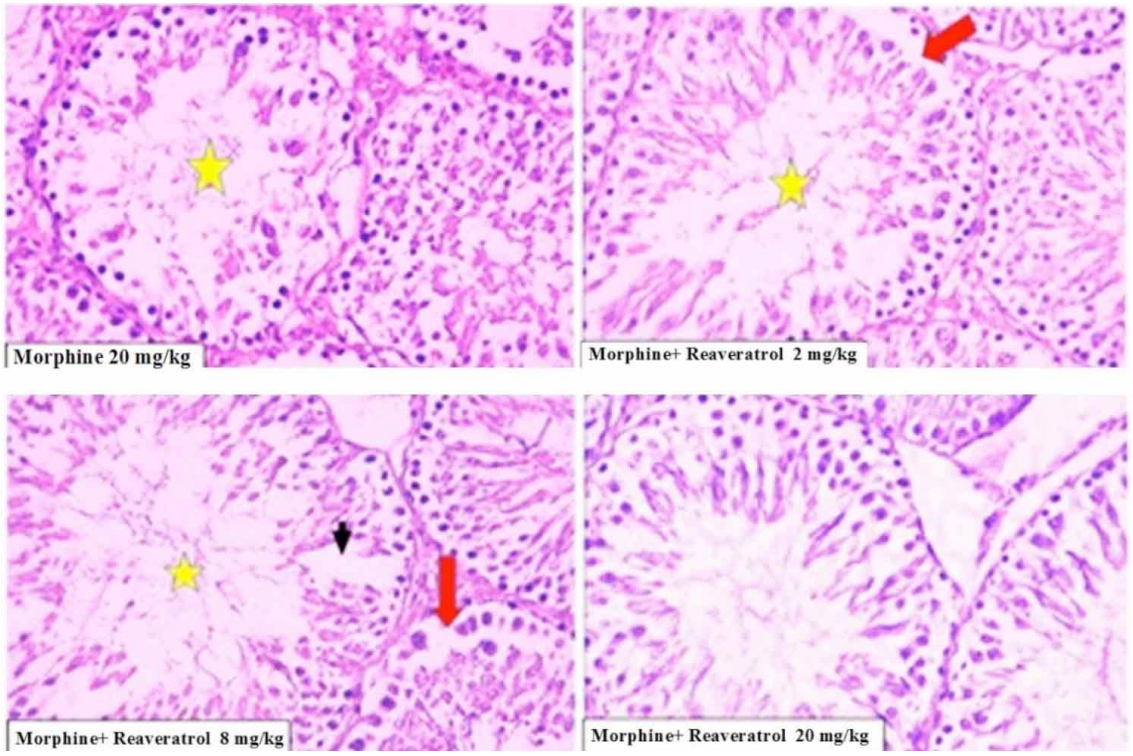

Fig. 2. Resveratrol and morphine effect on morphology of seminiferous tubules in mice. $\rightarrow$ Seminiferous tubules in the various stages of spermatogenesis: vacuolization of the seminiferous tubule epithelial, * reducing epithelium height and decreased sperm count, irregularities in the margins of seminiferous tubes (Magnification x400, stained $\mathrm{H} \& \mathrm{E}$ ).

\section{DISCUSSION}

The findings of the current research suggested that morphine could cause harmful effects on the testis weight, sperm parameters and seminiferous tubule architecture in the male mice, while resveratrol tended to reclaim them. 
JALILI, C.; SALAHSHOOR, M. R. ; JALILI, F; KAKABARAEI, S.; AKRAMI, A.; SOHRABI, M.; AHOOKHASH, M. \& GHANBARI, A. Therapeutic effect of resveratrol on morphineinduced damage in male reproductive system of mice by reducing nitric oxide serum level. Int. J. Morphol., 35(4):1342-1347, 2017.

This study showed that a higher dose of resveratrol $(20 \mathrm{mg} / \mathrm{kg}$ ) improved sperm quality, including motility, viability and morphology. Our findings were in line with studies which found resveratrol, as an antioxidant, had good effects on sperm production and motility (Mojica-Villegas et al., 2014). Oxidative stress, lipid peroxidation and changes in membrane properties induced by morphine resulted in the death of germ cells and reduced the sperm morphology and motility (Venkatesh et al., 2009), while antioxidants like resveratrol protected sperms from damage induced by free radicals through scavenging them (Ourique et al.).

In this study, resveratrol could significantly offset the damaging effects of morphine on seminiferous tubules. In other words, layer height of cell, tissue integrity and lumen diameter were significantly improved compared with the group receiving morphine. This feature arises when the parietal cells of seminiferous tubules in the group receiving resveratrol + morphine are quickly differentiated and released from the wall of the tubes, causing a slight increase in the internal diameter of tubes. Also, analysis of the left testicle weight showed a significant decrease in testicular weight between the groups receiving morphine and control group. In the group receiving morphine + resveratrol at doses of $20 \mathrm{mg} / \mathrm{kg}$, a significant increase in testicular weight was observed in comparison to the control group. Testis weight is significantly dependent on the density of cells in various stages of spermatogenesis. Weight reduction of testicles is related to the reduced size of seminiferous tubes lumen, stoppage of spermatogenesis and inhibition of steroid biosynthesis (Lakhman et al., 1989).

This study showed a significant decrease in testosterone levels between the groups receiving morphine and the control group as well as a significant increase in the group receiving resveratrol at a dose of $20 \mathrm{mg} / \mathrm{kg}$ compared with the morphine and control groups. In agreement with our results, Yilmaz et $a l$. showed that morphine reduced testosterone level and testis weight, and suggested that morphine might inhibit spermatogenesis in the testis with a direct effect on this organ. Juan et al. (2005) reported that production of spermatozoa was increased with resveratrol administration and resveratrol had therapeutic effects on the testes.

Studies have shown morphine can increase oxidative stress, leading to reduction of sperm parameters. Increasing free radicals has harmful effects on proliferation, activity and sperm fertility (Agarwal et al., 2004). The most important parameters for assessing the ability of fertilization and sperm membrane integrity are sperm mobility and sperm viability. Mammalian sperm membranes are sensitive to lipid per oxidation and contain large amounts of unsaturated fatty acids, resulting from oxidative stress, and reduce sperm motility and viability (Saleh \& Agarwal, 2002; Ozatik et al., 2013).
Our study showed that morphine increased nitric oxide level in comparison to the control group. It has been reported that high levels of NO induce apoptosis and inhibit the production of testosterone in sperm, thereby causing infertility (Lee \& Cheng, 2004; Doshi et al., 2012). Thus, the data of present research show increasing NO level is part of morphineinduced infertility. Therapeutic effects of resveratrol are more related to increased amount of antioxidants, and it is known that antioxidants can disrupt the nitric oxide system (protein enzymes, substrates and cofactors) (Das et al., 2005). Chehrei et al. recently showed that morphine administration stimulated inflammatory system by increasing the gene expression of Tool Like Receptors (TLRs), receptors related to inflammatory responses, in rats. On the other hand, Pajohanfar et al. (2017) confirmed that morphine exposure in rats elevated the level of both TLR-4 and iNOS in the brain of mice. Thus, the present study, in agreement with them, revealed that morphine exerted its side effects on tissues by increasing $\mathrm{NO}$ as a part of an inflammatory response while resveratrol reclaimed it.

\section{CONCLUSION}

The increased NO level in the present study confirmed the inflammatory effect of morphine, while resveratrol neutralized this effect of morphine by declining NO serum level as a part of anti-oxidant and antiinflammatory activity of this natural product. These beneficial effects of resveratrol led to improved sperm parameters (motility, morphology and viability) and histological characteristic of testis as well as increased level of testosterone in the morphine-treated mice.

ACKNOWLEDMENTS. We sincerely and gratefully thank Kermanshah University of Medical Sciences for providing the financial support of this project (No.94457).

JALILI, C.; SALAHSHOOR, M. R. ; JALILI, F; KAKABARAEI, S.; AKRAMI, A.; SOHRABI, M. \& AHOOKHASH, M.; GHANBARI, A. Efecto terapéutico del resveratrol sobre el daño inducido por la morfina en el sistema reproductor masculino de ratones reduciendo el nivel de óxido nítrico del suero. Int. J. Morphol., 35(4) :13421347, 2017.

RESUMEN: La morfina es uno de los alcaloides fenantreno del opio que induce efectos adversos en el sistema reproductivo masculino. El resveratrol es un fitoestrógeno y antioxidante de la uva roja. El objetivo principal de este trabajo fue investigar si el resveratrol puede inhibir los efectos adversos 
de la morfina sobre la viabilidad celular de los espermatozoides, el recuento y la motilidad, así como la histología de los testículos, la hormona testosterona y los niveles de óxido nítrico en ratones. Se dividieron, aleatoriamente, 48 ratas machos en 8 grupos $(n=6)$ y se trataron de forma intraperitoneal durante 14 días con solución salina normal, resveratrol $(2,8,20 \mathrm{mg} / \mathrm{kg} /$ día $)$, morfina $(20 \mathrm{mg}$ / kg / día ) y morfina (20 mg / kg / día $)+$ resveratrol (2, 8, $20 \mathrm{mg} /$ $\mathrm{kg}$ / día). Al final de los experimentos, se analizaron los parámetros espermáticos (viabilidad celular, recuento, motilidad y morfología), el peso de los testículos, el diámetro de los túbulos seminíferos, el nivel de la hormona testosterona y el óxido nítrico. Los datos fueron analizados con el software de SPSS para Windows (versión 20) usando una prueba de ANOVA de una vía seguida de la prueba post hoc de Tukey, y $\mathrm{P}<0,05$ se consideró significativo. Los resultados indicaron que la administración de morfina disminuyó significativamente el nivel de testosterona, el recuento, la viabilidad y la motilidad de los espermatozoides y el peso de los testículos, además del aumento de óxido nítrico en comparación con el grupo salino $(\mathrm{p}=0,000)$. La administración de resveratrol y resveratrol más morfina aumentó significativamente la motilidad, el recuento y la viabilidad de los espermatozoides, el diámetro de los túbulos seminíferos y la testosterona, mientras que disminuyó el nivel de óxido nítrico comparado con el grupo morfina $(\mathrm{p}=$ $0,025)$. En conclusión, la administración de resveratrol podría aumentar la calidad de los espermatozoides y prevenir los efectos adversos inducidos por la morfina sobre los parámetros espermáticos.

PALABRAS CLAVE: Ratones; Morfina; Óxido nítrico; Resveratrol; Espermatogénesis.

\section{REFERENCES}

Agarwal, A.; Nallella, K. P.; Allamaneni, S. S. \& Said, T. M. Role of antioxidants in treatment of male infertility: an overview of the literature. Reprod. Biomed. Online, 8(6):616-27, 2004.

Bai, Y.; Yang, H.; Zhang, G.; Hu, L.; Lei, Y.; Qin, Y.; Yang, Y.; Wang, Q.; Li, R. \& Mao, Q. Inhibitory effects of resveratrol on the adhesion, migration and invasion of human bladder cancer cells. Mol. Med. Rep., 15(2):885-9, 2017.

Chehrei, S.; Moradi, M.; Ghiabi, H. R.; Falahi, M.; Kaviani, S. \& Ghanbari, A. Pentoxifylline besides naltrexone recovers morphine-induced inflammation in male reproductive system of rats by regulating Tolllike receptor pathway. Andrologia, 2017. Epub ahead of print.

Das, S.; Alagappan, V. K.; Bagchi, D.; Sharma, H. S.; Maulik, N. \& Das, D. K. Coordinated induction of iNOS-VEGF-KDR-eNOS after resveratrol consumption: a potential mechanism for resveratrol preconditioning of the heart. Vasc. Pharmacol., 42(5-6):281-9, 2005.

Doshi, S. B.; Khullar, K.; Sharma, R. K. \& Agarwal, A. Role of reactive nitrogen species in male infertility. Reprod. Biol. Endocrinol., 10:109, 2012.

Jalili, C.; Ahmadi, S.; Roshankhah, S. \& Salahshoor, M. Effect of Genistein on reproductive parameter and serum nitric oxide levels in morphinetreated mice. Int. J. Reprod. Biomed. (Yazd)., 14(2):95-102, 2016.

Jalili, C.; Salahshoor, M. R. \& Naseri, A. Protective effect of Urtica dioica $\mathrm{L}$ against nicotine-induced damage on sperm parameters, testosterone and testis tissue in mice. Iran J. Reprod. Med., 12(6):401-8, 2014

Juan, M. E.; González-Pons, E.; Munuera, T.; Ballester, J.; Rodríguez-Gil, J. E. \& Planas, J. M. trans-Resveratrol, a natural antioxidant from grapes, increases sperm output in healthy rats. J. Nutr., 135(4):757-60, 2005.

Lakhman, S. S.; Singh, R. \& Kaur, G. Morphine-induced inhibition of ovulation in normally cycling rats: Neural site of action. Physiol. Behav., 46(3):467-71, 1989.

Lee, N. P. \& Cheng, C. Y. Nitric oxide/nitric oxide synthase, spermatogenesis, and tight junction dynamics. Biol. Reprod., 70(2):267$76,2004$.

Miranda, K. M.; Espey, M. G. \& Wink, D. A. A rapid, simple spectrophotometric method for simultaneous detection of nitrate and nitrite. Nitric Oxide, 5(1):62-71, 2001.

Mojica-Villegas, M. A.; Izquierdo-Vega, J. A.; Chamorro-Cevallos, G. \& Sánchez-Gutiérrez, M. Protective effect of resveratrol on biomarkers of oxidative stress induced by iron/ascorbate in mouse spermatozoa. Nutrients, 6(2):489-503, 2014.

Moradi, M.; Mahmoodi, M.; Raoofi, A. \& Ghanbari, A. Chorionic morphine, naltrexone and pentoxifylline effect on hypophyso-gonadal hormones of male rats. Bratisl. Lek. Listy., 116(4):276-9, 2014.

Motahari, A. A.; Sahraei, H. \& Meftahi, G. H. Role of nitric oxide on dopamine release and morphine-dependency. Basic Clin. Neurosci., 7(4):283-90, 2016.

Ourique, G. M.; Pês, T. S.; Saccol, E. M.; Finamor, I. A.; Glanzner, W. G.; Baldisserotto, B.; Pavanato, M. A.; Gonçalves, P. B. \& Barreto, K. P. Resveratrol prevents oxidative damage and loss of sperm motility induced by long-term treatment with valproic acid in Wistar rats. Exp. Toxicol. Pathol., 68(8):435-43, 2016.

Ozatik, O.; Aydin, Y.; Hassa, H.; Ulusoy, D.; Ogut, S. \& Sahin, F. Relationship between oxidative stress and clinical pregnancy in assisted reproductive technology treatment cycles. J. Assist. Reprod. Genet., 30(6):765-72, 2013.

Pajohanfar, N. S.; Mohebbi, E.; Rad, A.; Pejhan, A.; Nazemi, S. \& Amin, B. Protective effects of atorvastatin against morphine-induced tolerance and dependence in mice. Brain. Res., 1657:333-9, 2017.

Ranawat, P.; Khanduja, K. L. \& Pathak, C. M. Resveratrol - an ingredient of red wine abrogates the reproductive capacity in male mice. Andrologia, 46(6):650-8, 2014

Saleh, R. A. \& Agarwal, A. Oxidative stress and male infertility: from research bench to clinical practice. J. Androl., 23(6):737-52, 2002.

Venkatesh, S.; Singh, G.; Gupta, N. P.; Kumar, R.; Deecaraman, M. \& Dada, R. Correlation of sperm morphology and oxidative stress in infertile men. Iran. J. Reprod. Med., 7(1):29-34, 2009.

Wise, R. A. Dopamine, learning and motivation. Nat. Rev. Neurosci., 5(6):483-94, 2004.

Yilmaz, B.; Konar, V.; Kutlu, S.; Sandal, S.; Canpolat, S.; Gezen, M. R. \& Kelestimur, H. Influence of chronic morphine exposure on serum LH, FSH, testosterone levels, and body and testicular weights in the developing male rat. Arch. Androl., 43(3):189-96, 1999.

\section{Corresponding author:}

Ali Ghanbari

Fertility and Infertility Research Center

Kermanshah University of Medical Sciences

Kermanshah

IRAN

Email: aghanbari@kums.ac.ir

Received: 03-03-2017

Accepted: 19-07-2017 